\title{
Effects of methyl isocyanate on rat brain cells in culture
}

\author{
Diana Anderson, Shobha Goyle, B J Phillips, A Tee, Linda Beech, W H Butler
}

\begin{abstract}
Since the disaster in Bhopal, India, people exposed to methyl isocyanate (MIC) have complained of various disorders including neuromuscular dysfunction. In an attempt to get information about such dysfunction we have previously shown that MIC can affect muscle cells in culture. The present communication reports investigations into the effect of MIC on brain cells in culture. MIC was toxic to brain cells and the response was dose related. The observations were supported by light and electron microscopy.
\end{abstract}

In 1984 in Bhopal, India, there was an exothermic reaction in a storage tank at a pesticide plant, which resulted in leakage of $\mathbf{4 0}$ tonnes of methyl isocyanate (MIC) gas. The release of a chemical, on a scale unprecedented in recent history, left an estimated 15000 people suffering from a variety of ailments. After three months 50000 people were reported to have disorders of the eyes and lungs and ulceration of the gastrointestinal tract. Many complained of kidney, liver, and neuromuscular dysfunction. ${ }^{1}$

It has been shown that MIC is highly irritant to skin and mucosae and produces pulmonary oedema. ${ }^{2}$ At high exposure MIC caused death in rats, probably through reflex inhibition of breathing whereas surviving rats exhibited narrowing of the airways and haemorrhagic pulmonary oedema. ${ }^{3}$ The lesions were repaired rapidly but renewed inflammation and periobronchial fibrosis were apparent. Cyanide intoxication is not part of the clinical syndrome seen after exposure to MIC; nor does sodium thiosulphate protect rats from the acute and subacute effects of MIC. ${ }^{4}$ Cellular immunity is slightly compromised by MIC. ${ }^{5}$

The compound has been reported to be nonmutagenic in the standard Ames test ${ }^{6}$ and preincubation assay ${ }^{7}$ and negative results were also obtained in the Ames test when urine from animals treated with

The British Industrial Biological Research Association, Carshalton, Surrey SM5 4DS

D Anderson, S Goyle, B J Phillips, A Tee, L Beech, W H Butler
MIC was tested. ${ }^{\dot{ }}$ Shelby et al have reported a negative sex linked recessive lethal test in Drosophila. ${ }^{7}$ Positive results have been shown, however, for point mutation in the mouse lymphoma assay and for the induction of aberrations in chromosomes and sister chromatid exchanges in Chinese hamster ovary cells in culture in the absence of rat liver S9. ${ }^{7}$ There was marginal evidence of an effect giving rise to chromosomal aberrations and sister chromatid exchanges in the $\mathrm{B} 6 \mathrm{C} 3 \mathrm{~F}_{1}$ hybrid mouse but results were not reproducible. ${ }^{7}$ The results from the bioassay for carcinogenicity using the same strain have yet to be finalised, although other effects of MIC have been reported. ${ }^{9}$

There have been complaints of neuromuscular dysfunction in man but little is known of the toxicology of such effects. In an attempt to gain some information on muscular dysfunction we previously examined the effect of MIC on rat muscle cells in culture. ${ }^{10}$ In the present communication we report the effect of MIC when administered to rat brain cells in culture.

\section{Materials and methods}

ISOLATION OF NEURAL BRAIN CELLS AND CULTURE TECHNIQUES

Rat brain cells were isolated from foetal Wistar rats at 15 or 16 days of gestation (when cell migration is maximal) as described by Atterwill et al. ${ }^{112}$

Brains were dissected out into an ice cold solution pH 7.4 containing $\mathrm{NaCl}(138 \mathrm{mM}), \mathrm{KCl}(5.4 \mathrm{mM})$, $\mathrm{Na}_{2} \mathrm{HPO}_{4}(0.17 \mathrm{mM}), \mathrm{KH}_{2} \mathrm{PO}_{4}(0.22 \mathrm{mM}), \mathrm{CaCl}_{2}$ (1.8 mM), $\mathrm{MgCl}_{2}(0.8 \mathrm{mM}), \mathrm{D}$-glucose (5.5 mM), phenol red (14 $\mu \mathrm{M})$, gentamycin $(26 \mu \mathrm{g} / \mathrm{ml})$, and sucrose to make 340 mOsm (solution $D_{1}$ ).

The brains were washed twice with $100 \mathrm{ml}$ cold solution $\mathrm{D}_{2}\left(\mathrm{Ca}^{2+}\right.$ and $\mathrm{Mg}^{2+}$ free solution of $\left.\mathrm{D}_{1}\right)$ in a nylon gauze bag (Nybolt, pore size $250 \mu \mathrm{m}$ ). ${ }^{13}$ The brain cells were dissociated mechanically by extrusion through the gauze bag by gently stroking with a glass rod in $30 \mathrm{ml} \mathrm{D}_{2}$ solution. The suspension was refiltered through a Nybolt gauze bag $(130 \mu \mathrm{m}$ pore size) and centrifuged at $1000 \mathrm{~g}$ for five minutes $\left(0-5^{\circ} \mathrm{C}\right)$.

The tissue was mechanically triturated in $10 \mathrm{ml} \mathrm{D}$ solution using a $5 \mathrm{ml}$ pipette, and recentrifuged. The whole procedure was repeated twice and the final cell 
pellet was resuspended in $S+$ culture medium (a 3:1 mixture of Dulbecco's modified Eagle's medium and Hams F12 medium containing insulin $(5 \mu \mathrm{g} / \mathrm{ml})$, transferrin $(100 \mu \mathrm{g} / \mathrm{ml})$, progesterone $(20 \mathrm{nM})$, gentamycin $(25 \mu \mathrm{g} / \mathrm{ml})$, extra glutamine $(300 \mu \mathrm{g} / \mathrm{ml})$, trace elements according to Hutchings and Sato, ${ }^{14}$ and $10 \%$ foetal calf serum).

Cells were cultured in $\mathrm{S}+$ medium in $25 \mathrm{~cm}^{2}$ flasks and placed in a $\mathrm{CO}_{2}$ gassing incubator at $37^{\circ} \mathrm{C}$ until treatment.

\section{TREATMENT REGIME}

Solutions containing MIC were added directly to the flasks and left for one hour and then replaced by fresh medium. Flasks were incubated until fixation.

\section{EXPERIMENTAL PROTOCOLS}

Three experiments were carried out.

In the first, cultures were set up and treated on day five. A $50 \mu \mathrm{l} / \mathrm{ml}$ concentration of MIC (in medium) was added to flasks and mixed to give doses of 0.5 , $0.25,0.1$, and $0.05 \mu \mathrm{l} / \mathrm{ml}$ (control flasks containing medium without MIC were also included). This experiment was used merely for ranging doses and is not reported further.

In experiment 2 , cultures were set up and treated on day six at doses of $0.5,0.25,0.1$, and $0.05 \mu 1 / \mathrm{ml}$ MIC. There were eight cultures for each observation, three of which were used for light microscopy and five for electron microscopy. Cells for electron microscopy were fixed with glutaraldehyde and osmium tetroxide by the method of Hirsch and Fedorko $0^{15}$ after incubation for one hour, and at one and four days.

In experiment 3 cultures were treated on day seven at doses of $0.5,0.25$, and $0.1 \mu \mathrm{l} / \mathrm{ml}$ MIC. They were fixed either two or three days later. Three cultures were set up for each experimental observation on each day, one of which was used for light microscopy and two for electron microscopy. Cultures were fixed as in experiment 2.

\section{Results}

\section{EXPERIMENT 2}

\section{Day one post treatment}

Light microscopy-The control cultures showed a uniform population of undifferentiated cells but occasional cells were necrotic (fig 1). At a dose of $0 \cdot 1 \mu \mathrm{l} / \mathrm{ml} \mathrm{MIC}$ there was no significant difference between treated and control cultures (fig 2). At $0.25 \mu \mathrm{l} / \mathrm{ml}$ there was extensive necrosis within the aggregates (fig 3). At $0.5 \mu \mathrm{l} / \mathrm{ml}$ all the aggregates were necrotic (fig 4).

Electron microscopy - The ultrastructure of control cultures was compared with cultures treated with $0.25 \mu \mathrm{l} / \mathrm{ml} \mathrm{MIC}$. The control cultures showed a uniform population of cells that had long processes

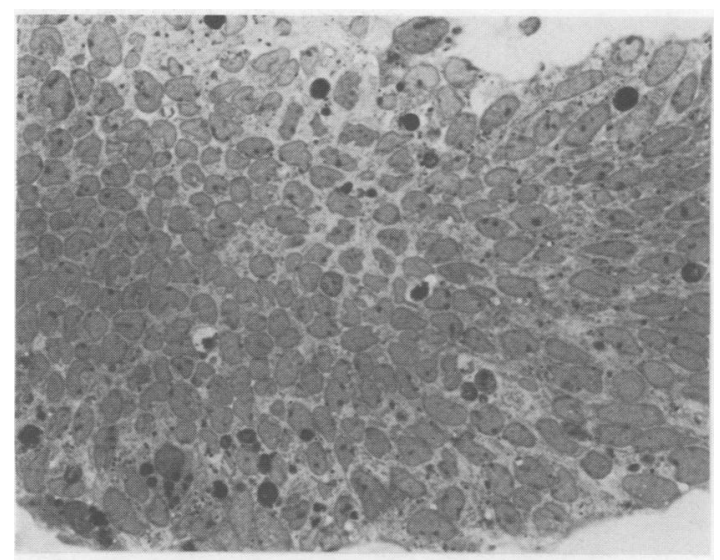

Figure 1 Section of control culture of cells derived from the brain after five days showing a uniform population of cells and occasional necrotic cells. Toluidine blue $\times 250$.

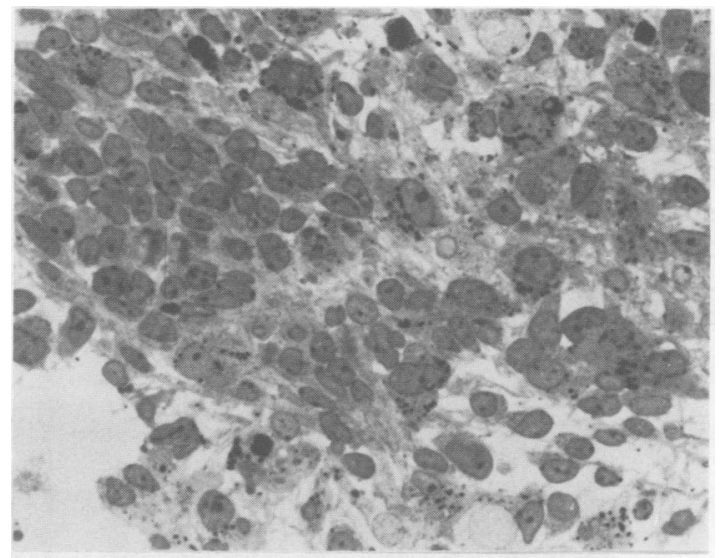

Figure 2 Section of culture of cells derived from brain treated with $0.1 \mu \mathrm{l} / \mathrm{ml} \mathrm{MIC}$; one day post treatment showing a uniform population of cells similar to controls. Toluidine blue $\times 250$.

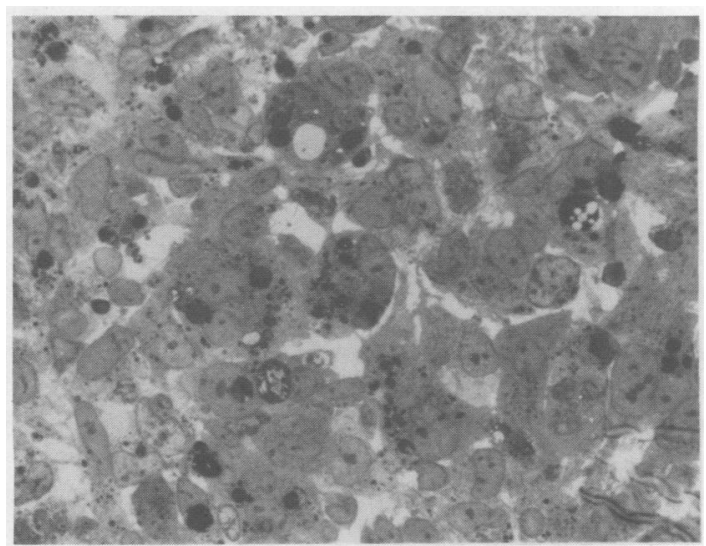

Figure 3 Section of culture of cells derived from brain treated with $0.25 \mu \mathrm{l} / \mathrm{ml} \mathrm{MIC}$ showing extensive necrosis. Toluidine blue $\times 250$. 


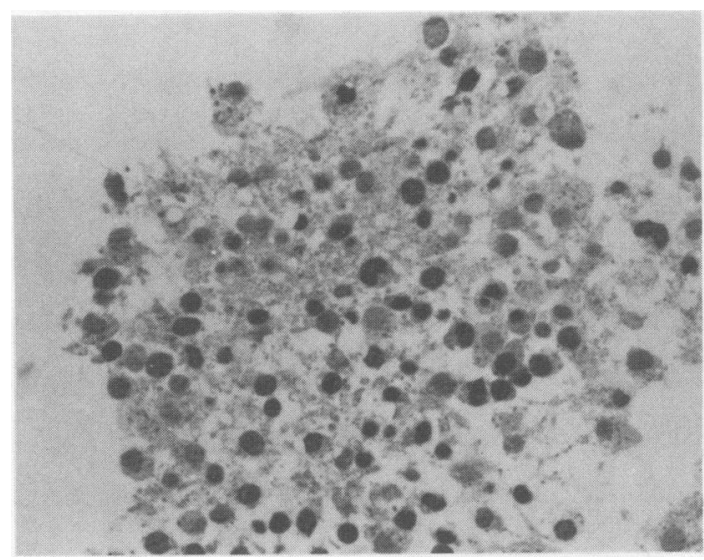

Figure 4 Section of culture of cells derived from brain treated with $0.5 \mu \mathrm{l} / \mathrm{ml} \mathrm{MIC}$; one day post treatment showing complete necrosis of culture. Toluidine blue $\times 250$.

with microfilaments in many areas. Other cells showed a collection of dense myelin-like figures sometimes in membrane bound vesicles (fig 5). Cultures treated with $0.25 \mu \mathrm{l} / \mathrm{ml}$ MIC showed some rarefaction of the cytoplasm (fig 6) and some dilatation of the rough endoplasmic reticulum. Cells containing myelin figures and apoptotic bodies were present throughout the culture (fig 7).

\section{Day four post treatment}

Light microscopy-All cultures showed marked degenerative changes. Control cultures had extensive necrosis within the colonies. Surviving cells showed many dense cytoplasmic inclusions (fig 8). Cultures treated with $0.25 \mu \mathrm{l} / \mathrm{ml}$ MIC were similar in appearance to controls (fig 9).

Electron microscopy-At the ultrastructural level, control cultures showed many necrotic cells with large autophagic vacuoles. Viable elongated cells had many long processes containing bundles of microfilaments that were endless. Treatment with $0.25 \mu \mathrm{l} / \mathrm{ml}$ MIC produced cultures very similar in appearance to the controls (fig 10).

\section{EXPERIMENT 3}

The control and treated cultures from experiment 3, seven days post treatment, did not survive sufficiently to determine the effects of treatment. This confirmed the observations of experiment 2 that the brain cells deteriorated with longer times in culture.

\section{Discussion}

The results show that MIC is toxic to brain cells in culture. By one day after treatment, MIC caused cell necrosis with evidence of a dose response relation. At a concentration of $0.5 \mu \mathrm{l} / \mathrm{ml} \mathrm{MIC}$ there were no apparent surviving cells although at $0 \cdot 1 \mu \mathrm{l} / \mathrm{ml}$ n⿺

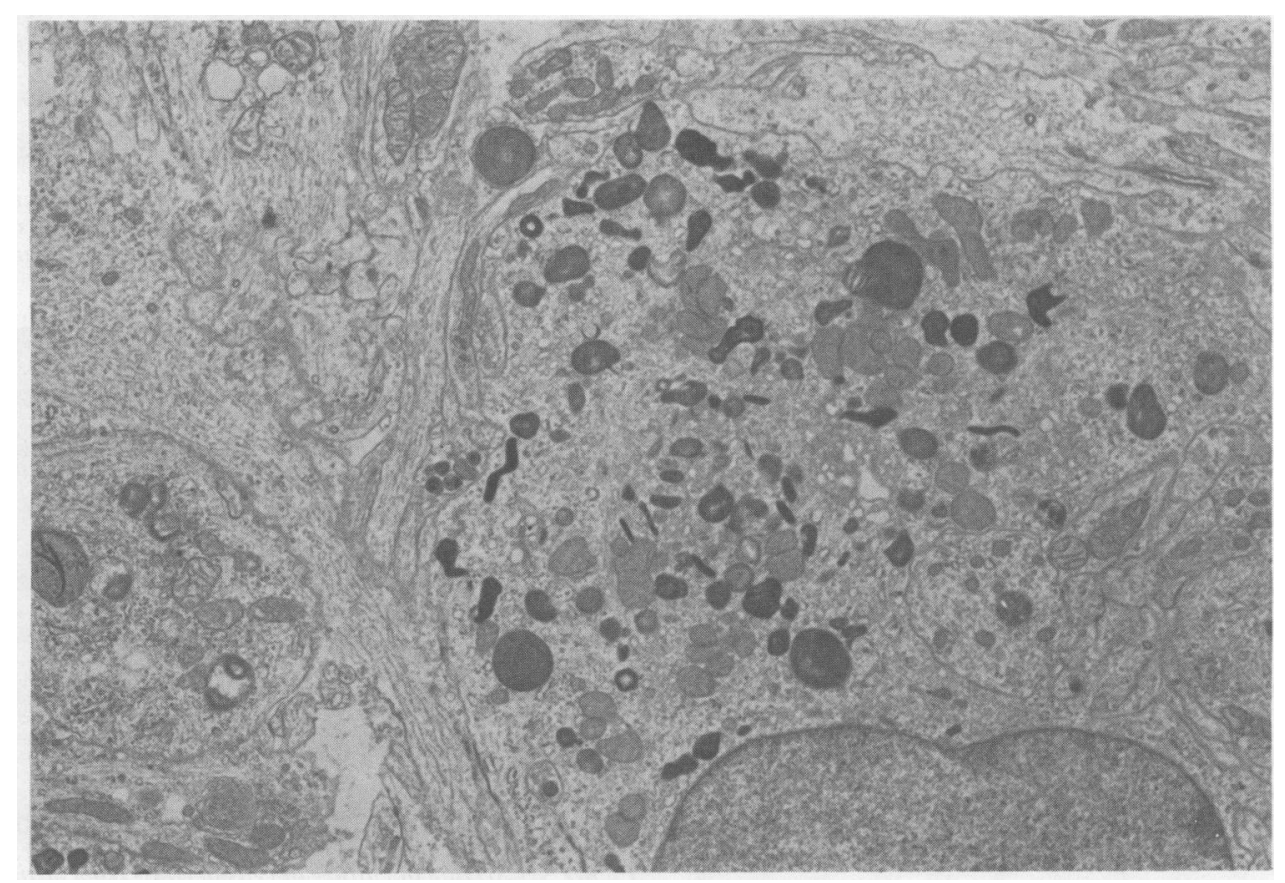

Figure 5 Ultrathin section of control culture showing a cell with long processes containing microfilaments and multiple dense myelin like bodies. $\times 8300$. 


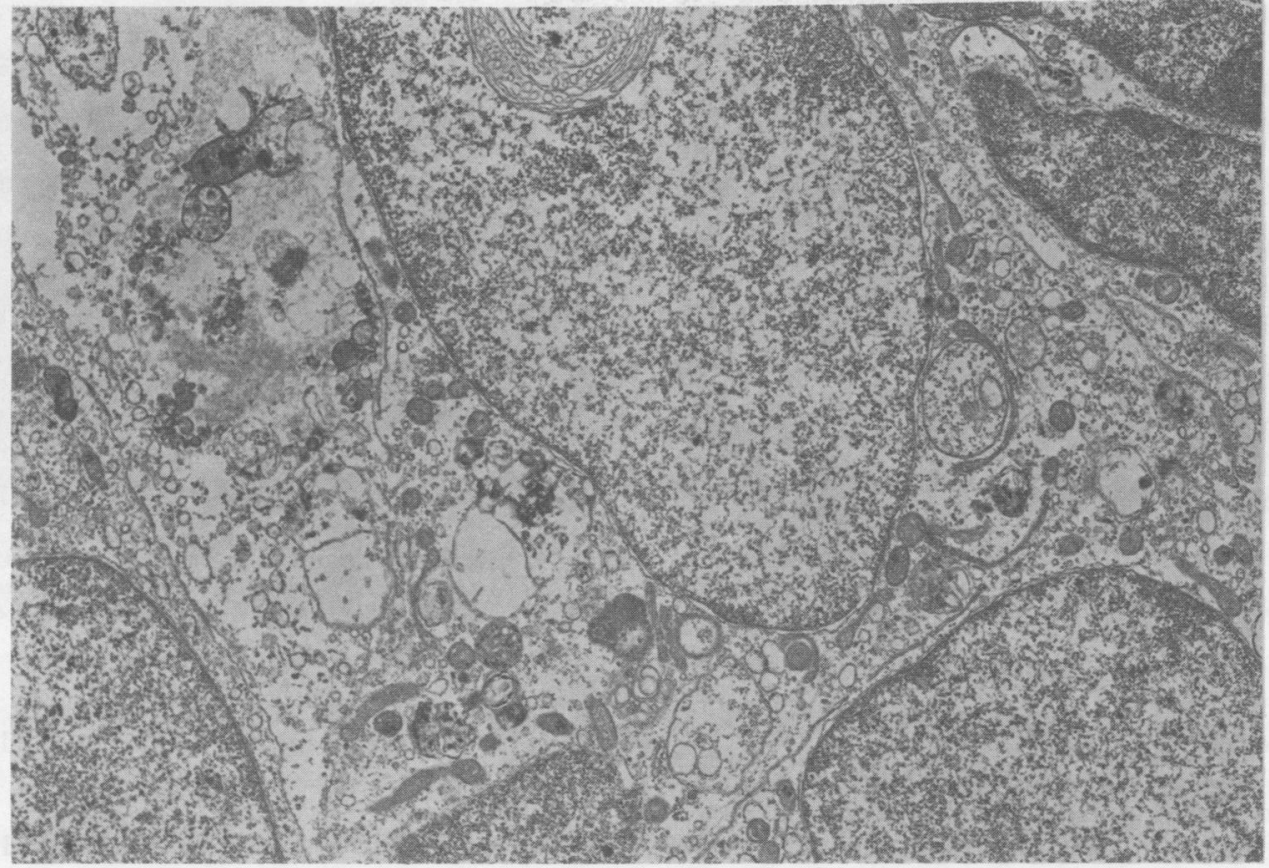

Figure 6 Ultrathin section of culture treated with $0.25 \mu \mathrm{l} / \mathrm{ml} \mathrm{MIC}$; one day post treatment showing rarefaction of cytoplasm and dilation of the rough endoplasmic reticulum. $\times 8300$.

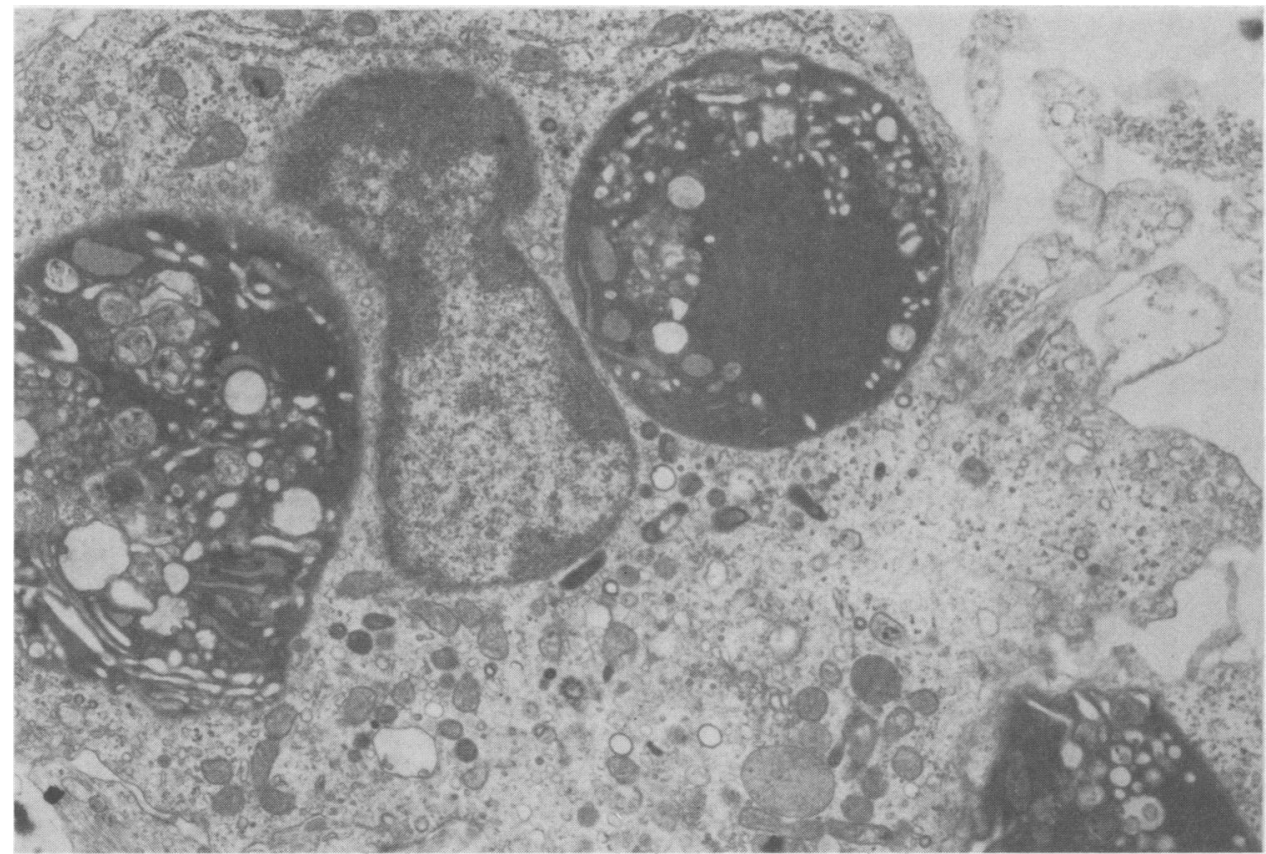

Figure 7 Ultrathin section of culture treated with $0.25 \mu \mathrm{l} / \mathrm{ml} \mathrm{MIC}$; one day post treatment showing large apoptotic bodies. $\times 12000$. 


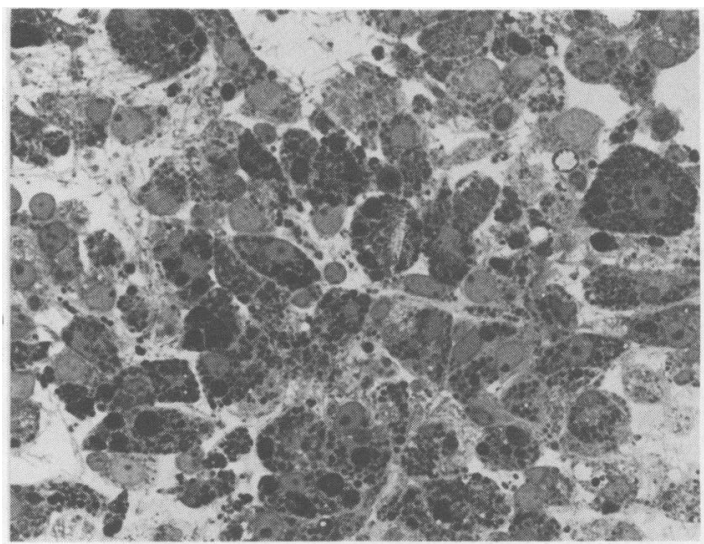

Figure 8 Section of control culture; four days post treatment, showing many dense cytoplasmic bodies. Toluidine blue $\times 250$.

toxic effect was observed suggesting a steep dose response relation.

With time a gradual deterioration of the cells occurred in all cultures; although there was a toxic effect at $0.25 \mu \mathrm{l} / \mathrm{ml} \mathrm{MIC}$ at day one, recognised by an increased number of necrotic cells, by day four the treated cultures appeared the same as the controls.

From this study and our previous one, ${ }^{10}$ it is apparent that MIC can affect both nerve cells and

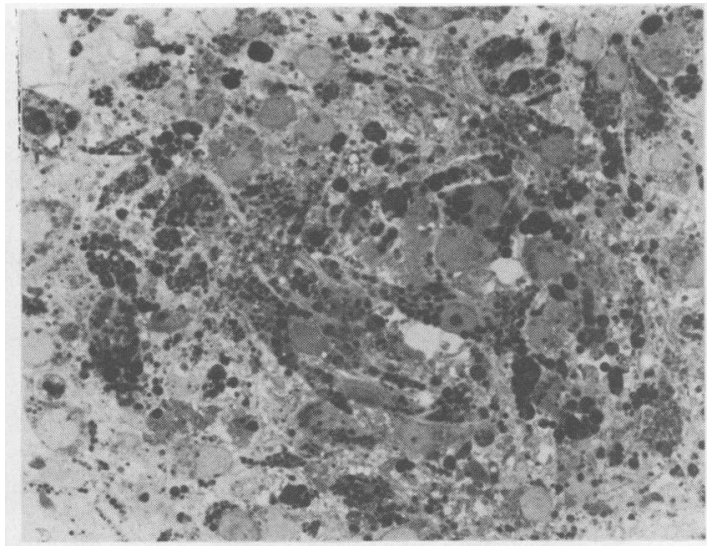

Figure 9 Section of culture treated with $0.25 \mu \mathrm{l} / \mathrm{ml}$ MIC; four days post treatment showing cells with multiple dense cytoplasmic bodies similar to controls. Toluidine blue $\times 250$.

muscle cells in culture, but the importance of the finding for nervous tissue in the intact animal is not clear.

Dr Shobha Goyle visited the British Industrial Biological Research Association Laboratories aided by funding from the Indian National Scienceo $₫$ Academy Exchange Programme and the Royas Society of Great Britain.

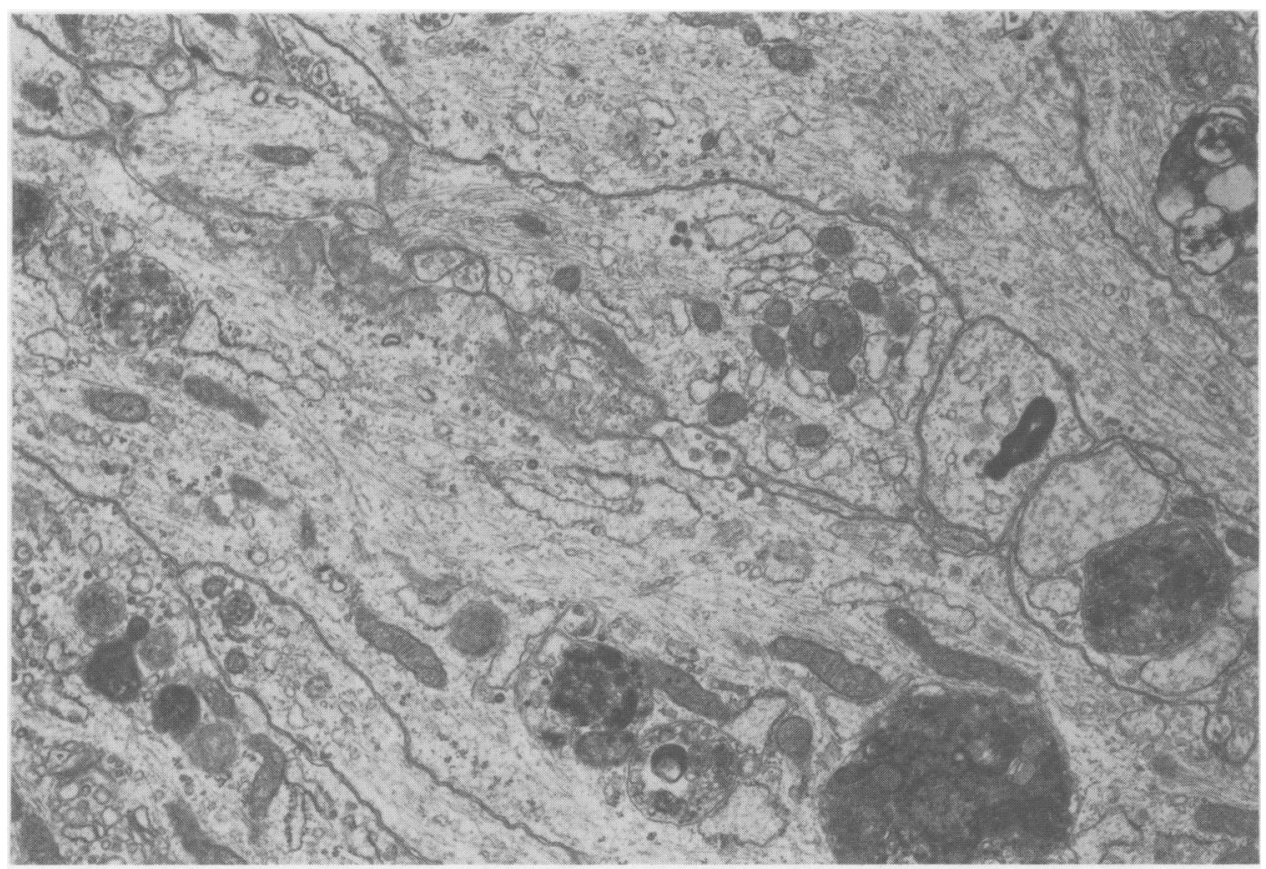

Figure 10 Ultrathin section of culture treated with $0.25 \mu \mathrm{l} / \mathrm{ml} \mathrm{MIC}$; four days post treatment showing cells with long processes and bundles of filaments. $\times 16500$. 
1 Zaida M. Bhopal and after. Am J Ind Med 1986;9:215-6.

2 Kimmerle R, Eben A. Zur Toxicität von Methylisocyanat und desen quantitativen Bestimmung in der Luft. Arch Toxicol 1964;20:235-41.

3 Nemery B, Dinsdale D, Sparrow S, Ray DE. Effects of methyl isocyanate on the respiratory tract of rats. $\mathrm{Br} J$ Ind Med 1985;42:799-805.

4 Nemery B, Sparrow S, Dinsdale D. Methyl isocyanate thiosulphate does not protect. Lancet 1985;ii:1245.

5 Silver M, Germalec D, Vore S, Tucker A, Luster M. Immunotoxicology of methyl isocyanate in mice. The Toxicologist 1986;6:78 (abstract No 31).

6 Department of Health and Human Services. National toxicology programme research, Triangle Park, North Carolina. Technical bulletin No 9 1983:5-6.

7 Shelby MD, Allen JW, Caspary WJ, et al. Results of in vitro and in vivo genetic toxicity tests on methyl isocyanate. Environ Health Perspect 1987;72:183-7.

8 Anderson D, Blowers SD, Nemery B. Investigation of the Ames test of urine samples from rats exposed to methyl isocyanate. Br J Ind Med 1986;43:566-7.

9 The toxicity of methyl isocyanate. Environ Health Perspect (special issue) 1987;72:1-313.

10 Anderson D, Goyle S, Phillips BJ, Tee A, Beech L, Butler WH.
Effects of methyl isocyanate on rat muscle cells in culture. $B r J$ Ind Med 1988;45:269-74.

11 Atterwill CK, Kingsbury A, Nicholls J, Prince A. Development of markers for cholinergic neurons in reaggregate culture of foetal rat whole brain in serum-containing and serum-free media: effects of iodothyronine $\left(\mathrm{T}_{3}\right) . \mathrm{Br} J$ Pharmacol 1984; 83:89-93.

12 Atterwill CK, Pillar A, Prince AK. The use of brain reaggregate cultures for studying cholinergic function and the effect of neurotoxic agents on the central nervous system. Food Chem Toxicol 1986;24:583-4.

13 Honegger $P$, Lenoir $D$. Triiodothyronine enhancement of neuronal differentiation in aggregating fetal brain cells cultured in a chemical defined medium. Brain Res 1980; 199:425-34.

14 Hutchings SE, Sato GH. Clonal growth of Hela cells in a defined medium. Proc Natl Acad Sci USA 1978;75:901-4.

15 Hirsch JG, Fedorko ME. Ultrastructure of human leukocytes after simultaneous fixation with glutaraldehyde and osmium tetroxide and "post fixation" in uranyl acetate. J Cell Biol 1968;38:615-27.

Accepted 3 April 1990 